\title{
Teologiese opleiding in Suid-Afrika:
}

\author{
'n Toekomsblik
}

\author{
J J Burden
}

Universiteit van Suid-Afrika

\begin{abstract}
Theological training in South Africa: A preview

What makes theological education theological? This question has been discussed from different perspectives in the past as well as in the present. The author concludes with his own definition of theological education: it is a dialogical event through which people partake in critical enquiry, testing the validity of religious witness. The unity and diversity - as well as the character-building and academic excellence - of theological education is discussed. The implications of this dialogue for our South African context is briefly considered.
\end{abstract}

\section{INLEIDING}

By ons eeuwenteling - en in hierdie geval te meer by die wisseling na 'n nuwe millennium - $k$ an 'n mens onrustigheid en 'n byna angsvallige soeke na verandering op alle lewensterreine verwag, soos tans ook duidelik blyk uit die politieke veranderinge in Suid-Afrika. Die eeuwisseling is natuurlik om goeie redes pregnant met verandering. Dit geld in 'n baie groot mate ook vir ons teologiese wêreld. Verskeie redes kan aangevoer word vir die noodsaaklikheid van verandering op teologiese gebied, veral van teologiese opleiding. Hervorming of ten minste vernuwing is volgens Ferris (1990:7) nodig omdat teologiese opleiding 'rigtingloos' is, fakulteite op 'n ongesonde wyse 'kompeteer', leerplanne 'lewensvreemd' is, en omdat kandidate 'swak voorberei' is vir die bediening. 'n Besonder belangrike rede is die verskuiwing in teologiese denke - veral wat betref die teologie van teologiese 
opleiding - wat die afgelope aantal dekades plaasgevind het. In Suid-Afrika bring politieke verandering daarbenewens tans groot verskuiwings op sosiale vlak mee wat noodwendig teologiese opleiding wesenlik moet en sal verander.

Ernstige vrae word rondom die aard, die vorm, die omvang, die metodologie, die inhoud, ensovoorts van teologiese opleiding gevra. Wheeler (1991:14) druk dit soos volg uit:

Virtually every well-known problem of theological education - the lack of integretation of the disciplines, the failure of the 'scholarly' aspect of theological education to have much effect in ministry, the theological aridity of most practical studies, the hegemony of white, male and Western history and experience - is anchored in the overall pattern of studies.

Blywende vernuwing in teologiese opleiding verg nie net 'n deurdringende ondersoek na die struktuur en die vooronderstellings en doelstellings wat dié strukture ondersteun nie, maar ook 'n kritiese beoordeling van die onderafdelings en die uiteenlopende inhoude daarvan asook 'n grondige herstrukturering van ons teologiese modelle in ooreenstemming met ons doelstellings en die waardes wat ons graag wil bevorder (vgl Wheeler 1991:4).

\section{RONDOM WOORDE EN BEGRIPPE}

In Afrikaans is dit moeilik om 'n presiese vertaling te vind vir 'theological education'. Ek gebruik in die opskrif die term 'opleiding' (wat met 'onderrig' ooreenkom) hoewel ek bewus is van die behavioristiese en selfs paternalistiese ondertone van dié twee woorde. Ek bedoel 'theological education' wat 'n breër begrip is as opleiding, onderrig of selfs onderwys.

Die vraag waarom dit gaan, is: 'What is theological education?' om dit in Engels te sê. Dit behels twee dinge: (a) kennisinhoud (of te wel: 'a body of knowledge') wat ons gewoonlik 'teologie' noem, en (b) die kommunikasieproses waardeur hierdie kennis oorgedra word, naamlik opvoeding. Teologiese 'opvoeding' beteken dus die oordrag aan iemand anders van dit wat ons reken ons van God en sy verhouding met sy skepping weet (Rooy 1986:51) en ervaar, moet ons byvoeg. Hierdie artikel handel gevolglik oor twee dinge, naamlik oor die teologie en oor die opvoeding in teologiese opleiding.

\subsection{Teologie}

Die woord 'teologie' kom nie in die Bybel voor nie, maar het in die vroeè verdediging van die Christelike geloof tydens die Grieks-Romeinse tydperk sy beslag gekry toe dit letterlik verstaan is as 'spreke oor God', wat beteken het 'n 
sistematiese uiteensetting van die Christelike geloof. Die gebruik van hierdie definisie kom van die subtitel: 'Geloofsoekende verstaan' ('Faith seeking understanding') wat Anselmus van Canterbury (1033-1109) aan een van sy boeke gegee het (vgl Taylor 1984:11). Hierdie definisie van teologie stel geloof voorop, 'n geloof wat daarop ingestel is om na te dink oor wat dit beteken om in God te glo. Hieruit is die apologetiese funksie van Christelike teologie ook te verklaar.

Teologie as rasionele denke werk egter beperkend. Geloof is immers iets wat ook gevoel en uitgeleef moet word en ons kan nie net daaroor nadink nie. Twee dimensies kom dus by die denke by, naamlik gevoel of ervaring en doen of dade.

Teologie is egter ook nie net ' $n$ vaste geloofsinhoud nie, maar dit is ook ' $n$ voortgaande proses, aangesien 'n lewende geloof verband hou met nuwe kennis en ontdekkings. Teologie word dus nooit afgehandel of voltooi nie en daarom herformuleer geloofsgroepe hulle leerstellings van tyd tot tyd in die lig van nuwe omstandighede.

Die tradisionele siening van teologie as finale normatiewe spreke oor God werk om die volgende redes beperkend op geloof in (vgl ook Taylor 1984:12-14):

\subsubsection{Teologie is verwyder van menslike ervaring}

Sommige geleerdes, soos Macquarrie (1977:5), lys ervaring as die vernaamste formatiewe bron van teologie. Kinders, vo6r die ouderdom van twaalf jaar wanneer logiese denke begin ontwikkel, het immers geloofs- en ander ervarings voordat hulle ernstig daaroor kan nadink. Volgens Moltmann (1980:55) is teoloë nie in ervaring as sodanig geïnteresseerd nie behalwe as hulle dit kan veralgemeen en op dié wyse in verband kan bring met die mens se toestand of met opvattings oor God. Maar dit bring verwydering tussen die denke en die gewone lewe sodat gebeurtenisse in mense se lewens moeilik met teologiese abstraksies in verband gebring kan word.

Benewens die rede en die ervaring - die twee tradisionele hoofbronne van die Westerse epistemologie - onderskei Gyekye (1987:201-202) paranormale waarneming (kognisie) in spiritisme, waarsêery en toordery in Afrika as 'n derde kenbron (cf Burden 1992:38). Dit beteken in werklikheid dat daar ernstige kenteoretiese probleme met die tradisionele definisie van teologie is.

\subsubsection{Teologie kan nie klinkklare Christelike antwoorde op spesifieke etiese vrae verskaf nie}

Teologie is uiteraard gemoeid met etiek, maar die vraag is hoe teologie onweerlegbare antwoorde op spesifieke etiese probleme kan verskaf. Teoloë en kerkgenootskappe verskil immers onderling oor konkrete oplossings vir spesifieke etiese probleme, soos byvoorbeeld aktiviste en pasifiste oor oorlog, en uiteenlopende standpunte oor homoseksualiteit, genadedood, aborsie, ensovoorts. 
2.1.3 Die onvermoë van teologie om 'n algemeen-aanvaarbare gesagsbron vir die geloof daar te stel

Tot voor die Verligting was die Bybel en tradisie die gesagsbron vir die Christelike geloof, maar sedertdien is ander gesagsbronne oorweeg, soos byvoorbeeld menslike ervaring vir empiriese teologie, prosesteologie, fenomenologie, dialektiese teologie, die klassestryd van die materialistiese maatskappykritiek, en historiese benaderings tot teologie (vgl Taylor 1984: 13-14). Vir 'evangelicals' is die Bybel natuurlik nog die enigste gesagsbron maar dit bied vir hulle ook geen waarborg vir onderlinge eensgesindheid oor teologiese aangeleenthede nie.

\subsubsection{Teologie lei nie direk tot opvoedkundige praktyke en metodes nie}

Daar is moontlik ' $n$ indirekte verband tussen teologie en opvoedkundige metodes aangesien 'n teologiese sisteem 'n eie aard en inhoud het wat 'n invloed op die opvoedkundige praktyk kan hê, soos in die geval van die opbloei van liberale teologie tussen die eerste en tweede wêreldoorlog as gevolg van die pragmatisme van John Dewey. Opvoedkundige metodes het egter 'n eie rasionaal wat op ervaring en proefneming gebou is. So kan verskillende kerklike groepering ewe goed van dieselfde visuele hulpmiddels of kleingroepmetodes gebruik maak al verskil hulle ook oor die teologie hemelsbreed.

\subsubsection{Tradisionele teologie is eksklusief}

Benewens hierdie vier beperkende aspekte wat Taylor noem, kan ons nog ook die eksklusiewe aard van Christelike teologie noem. Dit is eksklusief veral ten opsigte van ander godsdienste (vgl Tang 1988:5-9) en ook ten opsigte van vroue, 'grensgroepe' soos die armes en onderdruktes en sluit ook 'leke' uit. Tradisionele teologie is elitisties (vgl Bujo 1988:13-18) en hou nie rekening met die pluriforme en diverse samestelling van die moderne samelewing nie.

Die neiging is almeer om onder 'teologie' die geloofsbeoefening van die hele mens en van alle mense in te sluit. Dit beteken dit sluit alle mense se denke, ervaringe en handelinge wat aan hulle geloof uitdrukking gee, in. Dit geld natuurlik ook die beoefenaars van ander godsdienste (vgl Tang 1988:6), selfs al gebruik hulle nie self die benaming 'teologie' vir die beoefening van hulle geloof nie.

Hierdie nuwe siening is die gevolg van 'n paradigma-verandering: waar teologie 'n normatiewe van-bo- na-onder bedryf was, word dit nou 'n van-onder-na-bo handeling. Ons sou kon sè daar vind 'n 'demokratisering' van 'teologie' plaas wat die massas bevry van die oorheersing van die klerikale elite en hulle bekragtig ('empower') met hulle 'gereformeerde geboortereg', die amp van alle gelowiges. 


\subsection{Teologiese opvoeding}

Aanvanklik is 'opvoeding' in die letterlike sin van 'pedagogie', dit wil sê onderrig deur volwassenes aan kinders, verstaan. Hierin het groot verandering plaasgevind aangesien 'opvoeding' tans die leer en die onderrig omvat wat kognitiewe, affektiewe en konatiewe vaardighede insluit en wat handel oor die formele kommunikasie daarvan deur mense wat daaroor beskik aan ander wat dit nie het nie of minder daarvan het.

Teologiese opvoeding het uit die aard van die saak ook verander. Wheeler (1991:7) tipeer dié verandering soos volg:

[T] he term theological education usually refers to activities of seminaries and divinity schools, and sometimes is further specified as those activities that prepare clergy for their role and task. Several recent writers ... question the clerical orientation of contemporary theological education, and some ... argue that 'theological education' should be conceived broadly as all education, whatever the institutional locus, that has a theological character.

Daar het 'n verandering ten opsigte van vorm en inhoud van teologiese opleiding ingetree wat ek kortliks soos volg opsom (vgl veral Wheeler 1991:7-14):

\subsubsection{Veranderinge aan die vorm van teologiese opleiding}

\subsubsection{Deelnemende bestuur}

Waar teologiese opleiding in die verlede deur die hoofde of dekane van inrigtings bestuur is, neem fakulteitslede toenęmend deel aan die bestuur van die inrigtings.

\subsubsection{Teologiese opleiding word deur' $n$ akademiese benadering gekenmerk} Voorheen was die fokus meer op die professionele opleiding vir die bediening gerig terwyl dosente die afgelope dekade op die akademiese gehalte van hulle eie werk begin konsentreer het.

\subsubsection{Die teologie van teologiese opleiding word belangrik}

Wheeler (1991:8-9) laat haarself hieroor soos volg uit:

North Americans rarely participated in the long European tradition of arguing on theological grounds about how theological schools should define their mission, what should be included in the course of theological studies, and how those studies should be organized. 
Moontlik was teologiese opleiding in Suid-Afrika minder deur die Amerikaanse pragmatisme beïnvloed omdat dit oor die algemeen meer deur die liberalisme en rasionalisme uit Engeland en Europa onderskeidelik beïnvloed is. Wheeler (1991:9) se opmerking dat die diskussie 'have focused not on the theological rationale for a particular program of studies but rather on the theological orthodoxy of those who will be permitted to teach' is tot 'n groot mate wel ook op ons opleiding net so van toepassing. Teologiese opleiding is gevolglik nie as 'n teologiese probleem verstaan nie, maar as 'n praktiese aangeleentheid waarin die tegniek die klem dra (Wheeler 1991:9).

In die lig van 'n teologiese benadering tot opleiding het veral twee heersende konvensies onder skoot gekom. Eerstens, teologiese opleiding is voorbereiding van predikante vir die bediening. Dit het meegebring 'n verdeling in 'teologiese' en 'praktiese' vakke en die instelling van afsonderlike departemente vir die verskillende dissiplines. Voorstaanders van 'n teologiese benadering tot teologiese opleiding kritiseer juis hierdie versnippering omdat dit die teologiese karakter van die opleiding ondermyn (vgl Wheeler 1991:10). Die tweede konvensie onder skoot is die verstaan van teologiese opleiding as die toepassing van teorie in die praktyk. Daar is twee besware hierteen:

- dit gee aan alle nie-praktiese vakke ook die status van teorie-vir-klerikalepraktyke, en

- dit laat nie volkome reg geskied aan die ingewikkelde wyse waarop denke en aksie onderling verband hou nie.

\subsubsection{Verandering aan die inhoud van teologiese opleiding}

Een van die belangrikste struikelblokke wat die hersiening van leerplanne in ooreenstemming met die nuwe visie bemoeilik, is juis die struktuur waarvolgens teologiese studies in vier gebiede (Bybel, (sistematiese) teologie, kerkgeskiedenis en praktiese teologie) verdeel word. Hierdie struktuur skryf voor wat ingesluit word en hoe teologiese opleiding gedoen moet word. Hierdie struktuur skep twee ernstige probleme vir herbesinning en die vernuwing van teologiese opleiding, naamlik

\subsection{Dit gaan gepaard met uigediende aannames en norme}

Een van hierdie aannames is dat die Bybel die enigste en omvattende bron en norm vir alle teologiese kennis en godsdienstige handelinge is. Toe teologiese opleiding na die Verligting historiese en ander kritiese metodes begin insluit het, het hierdie histories-kritiese metodes die gesag van die teks wat as basis vir die praktyk gedien het, ondermyn. Hiermee saam hang die teorie-na-praktyk-aanname wat ons in 'n 
bepaalde denk- en handelingswyse indwing, naamlik 'n struktuur van drie 'teoretiese' dissiplines (soos hierbo aangedui) wat as fondament dien vir 'n groep 'praktiese' vakke.

\subsubsection{Dit bied tans geen oortuigende rasionaal of inherente logika nie}

Vroeër het hierdie struktuur darem die eenheid van die teologie aangedui, maar soos Wheeler (1991:12) dit verwoord: '[T]he structure now portrays not the order and unity of theology, but ... its fragmentation by diverse movements and developments of the last several centuries'.

Waarom kom so 'n belangrike belemmerende struktuur dan nie onder skoot nie? Waarskynlik omdat hierdie struktuur self een van die aannames geword het aangesien dit as vanselfsprekend aanvaar is (Wheeler 1991:13). ' $n$ Ander rede hang saam met die sosio-ekonomiese realiteit: Onafhanklike departemente en nuwe behoeftes verwerk kritiek en nuwe behoeftes deur nuwe kursusse in te stel en deur nuwe aanstellings of selfs deur samewerking tussen departemente maar hulle staan struktuurverandering teen om hulle eie posisie te beskerm (Wheeler 1991:14). Daar is egter tans tekens dat dit besig is om te verander. Die strukture en kenmerke van teologiese opleiding kom mos maar net uit die geskiedenis op en verouder en word uitgedien en verg daarom in nuwe omstandighede hersiening en vernuwing. Een van die nuutste tendense in die literatuur is juis 'n blootlegging van die behoefte aan struktuurvernuwing (Wheeler 1991:13).

\section{TEOLOGIESE OPLEIDING: 'N KORT TERUSKOUING}

Ons het nou gesien dat dit in teologiese opleiding oor 'teologie' ('a body of knowledge') en oor 'opvoeding' gaan. Hoe hierdie manier van verstaan van teologiese opleiding tot stand gekom het, kan uit die modelle wat oor die eeue ontstaan het, afgelees word. 'n Paar sulke modelle of 'teologiese kulture' verdien kortliks aandag (vgl Rooy 1986:52-67):

\subsection{Die kategetiese model}

Die eerste twee eeue van die oordrag van die Christelike geloof was afgestem op die voortsetting van die apostoliese tradisie waarin die verlossingswerk van God, die uitnodiging tot dissipelskap en die oorgawe aan Jesus Christus voorrang geniet het. $\mathrm{Na} 200 \mathrm{n} \mathrm{C}$ het 'n geleidelike verandering plaasgevind waar Christene by hulle doop sekere geloofswaarhede moes bely. Dit is gevolg deur 'n periode van geloofsvervolging wat gepaard gegaan het met aanvalle van die 'barbare' op die Romeinse ryk en die Christendom. 
In hierdie tydperk was daar drie fases van teologiese opleiding. In die eerste fase het die 'leke' waaronder die ouers, 'n belangrike rol gespeel. Eusebius (vgl Rooy 1986:54) gee die volgende beskrywing van hierdie fase: Leke het gepreek, aan die formulering van belydenisskrifte by sinodes deelgeneem, en in die geloof onderrig gegee. Die tweede fase was veral in die hande van die geestelikes. Nou het katkisante twee tot drie jaar onderrig in die apostoliese leerstellings ontvang voor hulle doop. Die doel hiervan was om dissipline in die morele lewe te bevorder, om kennis oor die Christelike tradisie te verwerf, en om 'n diep toewyding aan Christus en sy kerk te kweek (Rooy 1986:54).

Handboeke soos die Didache (van Irenaeus), die Apologie (van Justinus die Martelaar) en geskrifte van Tertulianus oor berou, die doop en gebed is in hierdie tyd in die kategese gebruik. In die derde fase het kategeseskole - soos dié van Aleksandrië, Antiogië, Edessa, Rome, ensovoorts - 'n belangrike funksie vervul om 'n godsdienstige dimensie aan studente se sekulêre opvoeding te gee.

Die hoofdoel van hierdie kategetiese model was om lidmate van die kerk voor te berei vir ' $n$ lewe getrou aan Christus en om in hulle getuienis voor ander mense redes vir hulle geloof te kan verskaf (vgl Rooy 1986:56).

\subsection{Die monastiese model}

Die geesdrif van die eerste eeue het afgeneem toe die Christelike geloof die staatsgodsdiens van die Romeinse ryk geword het. Die geestelikes het nou die plek van die gewone gelowiges ingeneem. Tertullianus het nog in $200 \mathrm{n} \mathrm{C}$ volgehou dat die kerk daar is waar twee of drie gewone gelowiges vergader, terwyl die Apostoliese Konstitusies dit verander het na 'wie die biskop hoor, hoor Christus' (Rooy 1986:56). Met sy terugkeer na Afrika in 388 het Augustinus die eerste skool vir priesters begin. Benediktus (oorlede 547) het 'n skool op Monte Casino begin waar monikke drie belangrike take gehad het: geestelike oefening, handearbeid en studie. Gedurende die Middeleeue het talle van hierdie kloosterskole dwarsoor Europa ontstaan. Daar het op dieselfde vlak as hierdie eerste inrigtings ook skole ontstaan wat aan die katedrale en paleise verbonde was. Daar was egter 'n gebrek aan die opleiding van gewone lidmate. Oor die opleiding van geestelikes laat Rabanus Marus (oorlede 856) hom ondubbelsinnig soos volg uit: 'An ecclesiastical education should qualify the sacred office of the ministry for divine service' (Rooy 1986:58). Die klem het veral op die opleiding van monikke en biskoppe geval terwyl selfs die opleiding van priesters afgeskeep is. Priesters moes gewoonweg van die een posisie na die ander op hulle eie vorder. 


\subsection{Die skolastiese model}

In die twaalfde eeu het die donker Middeleeue begin wyk en het daar uit katedraalskole (soos Notre Dame) en uit kloosterskole (soos Oxford) die eerste universiteite die lig begin sien. Die hoofdoel van die skolastiek was die suksesvolle sintese tussen geloof en rede, natuurlike teologie en openbaring, die aarde en die hemel. Die opsommings van die dogmatiek (summas) van die teologiese doktore van hierdie tyd het min relevansie gehad vir gewone lidmate en selfs vir die grootste gros geestelikes aangesien dit hoofsaaklik vir professore bedoel was.

Daar was verskillende redes vir die groeiende gaping tussen gewone lidmate en geestelikes waarvan die volgende die belangrikste was (vgl Rooy 1986:60): Eerstens, asketisme en mistisisme het 'n devaluering van die materiële wêreld en 'n vergeesteliking van die Christelike lewe teweeggebring. Tweedens, 'n magiese en bygelowige begrip van die wêreld het die gelowige se belange verplaas na die verre toekoms en die probleme van die huidige lewe onderevalueer. Derdens, die Middeleeuse kerk het amptelik die gesag en funksie van die geestelikes geskei van dié van die gewone gelowiges deur in dié verband te verwys na Deuteronomium 22:10: 'Jy mag nie 'n bees en 'n donkie saam voor 'n ploeg inspan nie'. Vierdens, goddelike gesag is deur sakramentalisme aan geestelikes verleen, waardeur hulle as instrumente van goddelike genade in die transsubstansiasie kon dien. Vyfdens, die geweldige teologiese verskuiwing van 'n ervaringsbelewenis van die evangelie na 'n rasionele verstaan daarvan het geen ruimte gelaat nie vir die emosionele stryd van gelowiges wat so tipies van die sosiale chaos van daardie tyd was en wat vir hulle in elk geval nie verstaanbaar was nie. Die simboliese kommunikering van die onbegryplike deur die sakramente was die metode van teologiese opleiding binne hierdie werklikheid. Simbole het die misterieuse werklikheid bekend gestel in so 'n mate dat by die ontvangs van die sakramente die gelowige Christus self (ex opere operato) ontvang het. In die Middeleeuse tetologie was simbole volop: die Bybel is deur die allegoriese metode simbolies verklaar; die doop van klein kinders word as kategese beskou; die besonderhede van die mis kry simboliese betekenis; die natuurlike wêreld is in geheel 'n geestelike sakrament. Dit lei daartoe dat teologiese opvoeding deur simbole geskied en nie deur die verkondigde woord nie. In hierdie metode het die onderrig en dialoog wat daaraan betekenis sou gee vir die gewone mense, ontbreek. Met dic ontstaan van universiteite het die belangstelling in gewone onderrig egter ook begin toeneem en is onderrig hoofsaaklik verskaf in die Tien Gebooie, die sewe doodsondes en in die sewe hoofdeugde om gelowiges te help in die aflegging van hulle belydenis. Die publikasie van die Lambeth Constitution (1281) in Engeland het gevolglik die opleiding van gewone priesters bevorder wat op hulle beurt weer gewone gelowiges moes leer. Dit het gelei tot die verwerping van die Skolastiese Teologie en 'n terugkeer na die studie van die Bybel en die Vaders. 


\subsection{Die kweekskool- of seminariummodel}

Die opstand en veranderinge wat die Reformasie in die sestiende eeu gebring het, is aan almal oorbekend. Een van die belangrikste redes vir vernuwing in teologiese opleiding was die morele verval van die geestelikes weens die gebrek aan inrigtings vir die vorming van priesters waar 'n hoë morele standaard gehandhaaf is en wangedrag dadelik opgespoor en uitgeroei is.

Ignatius Loyola kan beskou word as die grondlegger van die seminariummodel in die Rooms-Katolieke Kerk met die stigting van die kollege in Rome (1550) en die Duitse kollege (1551). Sy doelstelling was die vernuwing van die kerk in Italië en die herstel van die Duitse kerk deur 'n deeglike voorbereiding van hoogsgeskoolde jongmense. Die leerplan was gebou op hervormde skolastiek en Bybelstudies wat vir tien jaar opleiding voorsiening gemaak het: drie jaar filosofie, vier jaar skolastiese teologie en drie jaar sedeleer. In Engeland is elke katedraal en metropolitaanse kerk in 1563 deur 'n kerklike dekreet verplig om 'n seminarium vir die opleiding van priesters op te rig.

Die kerke van die Hervorming het hulle Christelike opvoeding gebaseer op hulle leerstelling van die amp van die gelowige: elkeen moet die Bybel kan verstaan en moet daarom geleer word hoe om dit te lees. Die stigting van die Akademie in Geneve (1559) dien as 'n goeie voorbeeld van die Reformatoriese idee van Christelike opvoeding. Daar was twee afdelings van die Akademie: 'n privaat voorbereidende skool met sewe vakke en 'n openbare skool met teoloë as professore wat gevorderde kursusse in 'geestelike' en 'sekulêre' vakke aangebied het. Die geestelike vakke het ingesluit (sistematiese) teologie, Bybeltale en eksegese.

Die verdere verloop van teologiese opleiding is moeiliker om kort saam te vat. Ná die Reformasie het die ortodoksie verstarring in die kerk gebring deur hulle oorbeklemtoning van die leerstellings. Die Reformasie het sy dinamiek verloor. Die gebrek aan leraars het daartoe gelei dat sommige opgelei was en ander nie. Die ideaal was egter nog altyd 'n goedopgeleide predikantekorps.

Die na-Reformatoriese tydperk is gekenmerk deur twee basiese vorme van teologiese opleiding vir predikante: (a) Die voortsetting van universiteite (in Engeland en Europa) asook die oprigting van kolleges (in Noord-Amerika), waar gewone en godsdienstige onderrig met 'n teoretiese inslag gekombineer is; en (b) Godsdiensonderrig is geleidelik in koloniale Amerika geskei van gewone onderwys en teologiese seminariums is sodoende gestig.

Samevattend kan ons die volgende van hierdie vier modelle sê: Die kategetiese model met sy pastorale klem kom vandag nog as 'Christelike opvoeding' voor in die hoofstroom van die Christendom. Die monastiese model is om teologiese redes deur 'evangeliese' kerke tydens die Reformasie verwerp, maar sy asketiese en mistiese 
elemente bestaan nog voort in piëtistiese gemeenskappe wat hulle hermeties inklooster en hulle van die wêreld afskei. Die skolastiese model is met ongekende geweld deur die Hervormers verwerp om maar net na 'n paar geslagte weer in die geslote dogmatiese sisteem van die Ortodoksie terug te keer. Kennis as doel opsigself het immers by ons teologiese inrigtings oor die eeue gespook en ons oë voortdurend vir ons eietydse probleme gesluit deur buitengewone klem op ortodoksie te lê wat ortopraksie maklik uitsluit. Die na-reformatoriese seminariummodel met sy eensydige klem op die professionele opleiding van die predikant in plaas van op die gelowige as 'volgroeide mens' (Ef 4:13) het ons so betower dat ons dit moeilik vind om dit nie as die finale antwoord par excellence ook vir ons moderne wèreld te beskou nie. Rooy (1986:68-69) druk dit so uit: 'The sacred cow of the seminary is untouchable, if not because we love it, then because we lack the openness and creativity to search for other ways'. Wanneer ons hierdie vroeë modelle van teologiese opleiding bestudeer moet ons ook die 'ekologie van teologiese opleiding' in gedagte hou: die sosiale, politieke en kulturele konteks het gehelp om elke model te vorm (Rooy 1986:51). Dit geld natuurlik ook vir hedendaagse modelle en sal in die toekoms ook geld. In hierdie modelle is teologie normatief verstaan: dit handel oor die kennis van God soos Hy Homself aan ons openbaar het. Om God te leer ken het ons 'kenners' van God - geleerde geestelikes - nodig om die bonatuurlike vir ons te verduidelik. Daarbenewens het die klem op karaktervorming in teologiese opleiding geval. Hierdie modelle het uiteraard 'n groot rol gespeel in die siening en praktiese implementering van teologiese opleiding dwarsdeur die eeue en tot op die hede.

\section{DIE DRIE 'PUBLIEKE' VAN TEOLOGIESE OPLEIDING}

Bosch (1992:8-23) bekyk die geskiedenis van teologiese opleiding op 'n ander wyse deur op voetspoor van Tracy (1981:3-46) drie dimensies of 'publieke', naamlik die universiteit, die kerk en die gemeenskap oftewel theoria, poiesis en praxis (vgl Stackhouse 1988:84-135) te onderskei. Hierdie terme kom uit die klassieke filosofie waarvolgens theoria insluit waarneming, verslagdoening, interpretasie en kritiese evaluering; poiesis beteken die skepping van beelde wat hulle manifesteer in aanbidding, liturgie en belydenis; en praxis wat insluit opsetlike praktiese betrokkenheid waardeur mense probeer om die goeie te doen. Bosch (1992:9) verbind hierdie drie woorde aan Kant se onderskeid tussen die drie basiese vrae van die mens, te wete: Wat kan ek ken? (theoria); Wat mag ek hoop? (poiesis); en Wat moet ek doen? (praxis). Aangesien Bosch hierdie drie 'publieke' redelik breedvoerig uitwerk, is dit nie nodig om dit hier verder te verduidelik nie. Ek sou wel nie soos Bosch hierdie drie 'publieke' as die aard van teologiese opleiding wou tipeer 
nie, maar eerder as die 'agentc' betrokke daarby en dan wou opmerk dat die eerste twee (die universiteit en die kerk) subjekte is en dat die derde (die maatskappy) die objek is - wat Bosch (1992:16-19) self ook uitwys. Verdere probleme tot hierdie benadering sal in die loop van die bespreking weer onder die loep kom.

\section{WAT MAAK TEOLOGIESE OPLEIDING TEOLOGIES?}

\subsection{Ter inleiding}

Die vraag hierbo dui op die essensie van die debat oor teologiese opleiding in Europa en veral ook in Amerika die afgelope dekade of meer. Die gesprek handel nie tans oor pedagogiese of strukturele nodelle soos tot onlangs nie; nie oor vrae soos: Wat is die effektiefste metode of struktuur vir teologiese opleiding? nie; of: Watter verbeteringe moet aan leerplanne en onderrigmetodes aangebring word? ensovoorts nie. Die kernvraag is: Wat is die aard en doel van teologiese opleiding spesifiek? Wat onderskei dit van ander verwante akademiese dissiplines? Kortom: Wat is teologies aan teologiese opleiding (vgl Kelsey 1993:1-2)?

Dit handel veral oor twee breë sake, naamlik oor eenheid en oor pluralisme in teologiese opleiding (Kelsey 1993:95-100). Albei het te make met die 'Christian thing' en met hoe teologiese opleiding daarmee verband hou. Die 'eenheid' handel oor die vraag: Gee die teologiese inrigting se kursusse voldoende uitdrukking aan die inherente eenheid ('integriteit' of 'identiteit') van die 'Christian thing'? 'Pluralisme' weer het te make met die vraag: Gee die kursusse van die teologiese inrigting voldoende uitdrul:king aan die pluralistiese wêreld waarin die 'Christelike ding' uitgeleef moet word?

'Eenheid' en 'pluralisme' is teoretiese begrippe wat wel vaag en dubbelsinning is. Die betekenis van 'eenheid' hang af van hoe ons die 'Christelike ding' verstaan. Handel die 'Christian thing' oor 'n koherente groep leerstellings met 'n soort eenheid soos dié van 'n stuk teorie? Of: moet ons die eenheid verstaan soos dié wat die persoonlikheid van 'n mens uitmaak? 'Pluralisme' weer hang saam met ons verstaan van die wêreld? Sluit dit verskillende kulture in dan kom sake soos 'kontekstualisering' en 'globalisering' ter sprake. Dit kan ook insluit verskillende 'godsdienste' of die 'sosiale werklikheid' wat onderskeidelik interreligieuse dialoog reweegbring of wat handel oor geslags-, rasse-, politieke of ekonomiese sake (vgl Kelsey 1993:97-100).

'n Ander aspek van die gesprek handel oor die persoonlikheidsvorming van teologiese studente en hulle akademiese of wetenskaplike vorming. In sy jongste boek Between Athens and Berlin onderskei Kelsey (1993:19-27) met die name 'Atene' en 'Berlyn' tussen hierdie twee dimensies. In die Atene-model val die klem 
op die student. Natuurlik fokus die studie op verskillende vakinhoude, maar is so ingerig dat die klem op studente se persoonlike verwerwing van wysheid oor God en oor hulleself in relasie tot God val. Hierdie model gaan natuurlik terug op die Griekse paideia, wat beteken ' $n$ kultiveringsproses waar dit gaan om karaktervorming. Die vroeë Christene wat in 'n Hellinistiese milieu groot geword het, het hulle Christenskap en opvoeding in die lig van die Griekse paideia verstaan. Natuurlik het hierdie idee deur 'n aantal veranderings gegaan waarop ons nie hier hoef in te gaan nie. Dit is wel interessant om te weet dat die doel van opvoeding as paideia aanvanklik van openbare en politieke belang was: die opvoeding van burgers om in die politiek van 'n demokratiese selfregerende polis of stad hulle plek vol te staan. Wat vir Christene wel van belang was, is dat die doel van paideia van die openbare na die private domein verskuif het en dus vir hulle verskuif het van 'n voorbereiding vir openbare en politieke aksie na 'n innerlike godsdienstige transformasie. Gevolglik was die Christelịke geloof later vir Klemens van Aleksandrië $\epsilon$ n vir Origenes nie net soos paideia nie, of kon dit in opvoeding daarvan gebruik maak nie, maar die Christelike geloof is paideia, wat deur God in Jesus gegee is tot 'n radikale bekering deur die werk van die Heilige Gees (vgl Kelsey 1993:11). Ons kan dus die sterk invloed van die Atene-model in die teologiese opleiding van baie groepe verstaan. Vir hulle is die doel van teologiese opleiding kennis van God en gevolglik 'forming persons' souls to be holy' (Kelsey 1993:11).

Die Berlyn-model (vgl Kelsey 1993:12-19) het sy naam te danke aan die stigting van die Universiteit van Berlyn in 1810. Die doel van Wilhelm von Humboldt met hierdie universiteit was tweërlei: Wissenschaft of ordelike, gedissiplineerde navorsing en professionele opleiding. Die vraag was of 'n teologiese fakulteit tuishoort by 'n navorsingsuniversiteit. Friedrich Schleiermacher was op die driemanskomitee wat die statute van hierdie universiteit moes opstel en was terselfuertyd die eintlike outeur van die stigtingsdokument. Hy moes die insluiting van 'n teologiese fakulteit motiveer aan hierdie universiteit wat net doktorsgrade sou toeken en waar slegs gedoktoreerdes dosente kon wees. Die rede vir die insluiting van 'n teologiese fakulteit lê vir Schleiermacher juis in die idee van navorsing. Paideia sluit immers ook ondersoek in, veral in klassieke tekste (van Homerus en Plato) wat as gesaghebbend beskou is. Hierdie navorsingsuniversiteit moes egter radikaal-krities wees deur veral krities te wees oor hulle gesagsbronne of basisse van waarheid. Gevolglik tel in beginsel die ouderdom van 'n standpunt, of die persoon wat dit huldig, of selfs goddelike openbaring nie vir die aanvaarding van daardie gesag nie. Verder is navorsing onderworpe aan die dissipline van 'n metode en aan die ordening van 'n groep verbandhoudende sake. Volgens hierdie model tel slegs die resultate van navorsing wat as wetenskaplik beskou word as 'kennis'. 
Omdat teologie tradisioneel op 'openbaring' as kenbron staatgemaak het, is die plek daarvan aan so 'n navorsingsuniversiteit betwyfel. Daarmee saam het teologie die vryheid om na goeddunke te leer en om te onderrig bedreig vanweë 'n voorafingenome geloofstandpunt.

Schleiermacher voer egter sosiologiese en filosofies-teologiese argumente aan vir die insluiting van teologie as professionele opvoeding. Die sosiologiese argument is dat medisyne, regte en teologie die welwese van die maatskappy moet dien. Schleiermacher gee egter toe dat teologie nie by die 'suiwer' wetenskappe tuishoort nie, aangesien die beginsel daarvan nie van universele beginsels, wat vir alle navorsers beskikbaar is, afgelei kan word nie. Teologie is vir hom egter gewortel in die kerk met spesifieke historiese en kulturele beginsels. Dit is dus 'n 'positiewe', 'n stellige wetenskap wat doodeenvoudig 'n 'gegewene' ('posited') is (vgl Kelsey 1993:16). Die Christendom berus vir hom gevolglik nie op 'geopenbaarde' beginsels nie, maar op intuisie of op insigvolle ervaring wat die onderwerp van filosofiese ondersoek en dus ook van wetenskaplike navorsing kan wees sonder om die integriteit van die Christendom of die universiteit in gedrang te bring.

Dit is interessant hoe Schleiermacher die teologiese dissiplines benoem en regverdig: 'Christelik' kan eerstens deskriptief gebruik word in die historiese vakke wat insluit Christelike praktyk, onderrig en tekste (insluitend die Bybel); dit kan tweedens ook normatief gebruik word in filosofiese teologie wat na die wesentlike dinge vra. Derdens kan dit ook die reëls neerlê vir die Christelike bediening of die praktiese teologie wat vir hom 'n teoretiese onderneming is.

Teologie is op twee gronde aan die Berlynse universiteit gevestig: die interafhanklikheid van die opvoeding vir die wetenskap en vir professionele doeleindes. Hierdie tweeledigheid vorm die basis van alle teologiese opleiding wat op die Berlyn-model geskoei is.

\subsection{Vyf modelle}

Standpunte loop uiteen oor wat teologie is en hoe om studente in staat te stel om teologie te doen. Ons onderskei hier vyf moontlike sienings:

\section{2 .1 'n Teorie-na-praktyk benadering}

Stackhouse (1988:184-208) sien teologie as 'n soort teorie wat op die lewe van toepassing gemaak kan word. As teorie is teologie universeel en kruis-kultureel aanvaarbaar en is dit 'objektief' want die vermoë van die menslike rede is oral en altyd dieselfde. Die vraag is egter: Watter soort teorie is teologie? Die aard en doel daarvan hang af van die professionele kerkleierskap. Dit is met ander woorde 'kerkteologie' waarvan die hoofdoel apologia is. Deur teologiese opleiding leer die 
student die formulering en verdediging van leerstellings oor God se geregtigheid en waarheid vir Christengemeenskappe wat wêreldwyd van toepassing is. Die beweging van teorie-na-praktyk maak teologiese opleiding teologies. Hierdie benadering volg die Berlyn-model want dit lei die professionele kerkleierskap op in die historiese en veral die filosofiese 'Wissenschaft' (vgl Kelsey 1993:173-193).

Vir Stackhouse lè die 'wetenskaplikheid' van teologie in die ondersoek na God se waarheid en die 'vroomheid' daarvan in die ondersoek na God se geregtigheid (vgl Kelsey 1993:191). Hierdie twee sake is moeilik om koherent bymekaar te hou en Stackhouse se siening oor die redelike vermoëns van die mens word ook betwyfel (Kelsey 1993:190-191).

\subsection{2 'n Geloof-binne-sy-eie-situasie benadering}

Vir Farley (1983 en 1988) is teologie - hy praat eerder van 'theologia' - 'n soort wysheid en nie 'n teorie oor God nie. Hierdie 'theologia' moet in terme van sy verband met geloof verstaan word. 'Theologia' behels twee dinge: (a) die gelowige se neiging om dinge op'n spesifieke manier te doen (genoem sy habitus = houding), en (b) sy dialektiese aktiwiteit. 'Theologia' het twee kante, 'n objektiewe kant en 'n subjektiewe kant. Eersgenoemde is die 'geloofswêreld' wat bestaan uit beelde, leerstellings, vorms van gemeenskapslewe, ensovoorts - 'n wêreld waarin die gelowige lewe sonder ernstige nadenke. In die tweede of dialektiese aktiwiteit is die menslike subjek betrokke en is 'theologia' geloof se eie interne proses van nadenke. Volgens hierdie benadering is teologiese opleiding teologies wanneer studente deur die habitus van teologie (paideia) gevorm word en betrokke raak in kritiese denke.

Die kritiek teen hierdie benadering wys op die gebrek aan openbare betrokkenheid en die gevaar van die 'privatisering' van geloof (vgl Kelsey 1993:192193). Daar is veral ook twyfel oor die interne koherensie van 'theologia' as habitus en as dialektiese aktiwiteit (Kelsey 1993:121-134).

In hierdie benadering sien ons positiewe aspekte van die Atene-model (die habitus) en die Berlyn-model (die dialektiese aktiwiteit) wat die hele mens aan die teologie wil bloot stel.

\subsection{3 'n Benadering van konkrete ervaringe}

Hierdie benadering word in God's fierce whimsy bepleit deur die 'Mud Flower Collective' (1985) wat uit sewe vroue-teoloë bestaan (vgl Kelsey 1993:135-153, 193194). Volgens hulle is Christelike teologie die nadenke oor 'n persoon se konkrete ervaringe van verhoudinge. Dis 'n nadenke wat geregtigheid wil vestig. Ons ervaar God se teenwoordigheid of sy afwesigheid in en deur persoonlike verhoudinge en nie deur kerkleierskap (Stackhouse) of deur geloof (Farley) nie. As refleksie oor 
persoonlike verhoudinge is teologie 'n subjektiewe maar nie 'n private aangeleentheid nie, want dit is konkrete ervaringe van sosiale, ekonomiese, politieke en kulturele mag. Daarom het dit ook altyd met geregtigheid in die private en openbare lewe te make. Die konkreetheid van teologie lê ook daarin dat dit altyd ingebed is in historiese en kulturele kontekste wat onderling verskil. Om hierdie rede sal teologie altyd pluralisties wees. Ervarings van God verskil immers net soos ervarings onder mense. Teologiese opleiding is dus die vorming van mense se vermoëns om andere se weergawes van hulle ervaringe van persoonlike verhoudinge te hoor, en die ontwikkeling van die vermoë om jou eie verhale op so 'n wyse te vertel dat God se teenwoordigheid daarin duidelik blyk.

Hierdie benadering volg die Athene-model behalwe dat dit die siening van ' $n$ universele 'essensie' van menswees of van menslike ervaring verwerp (Kelsey 1993:194). Dit verwerp ook die aanname van die eerste twee benaderings dat daar 'n universele, ahistoriese, kruis-kulturele 'essensie' of struktuur van die inhoud van teologie of van die kursusstruktuur daarvan is.

'n Paar punte van kritiek moet uitgelig word: (a) đie noodsaaklikheid van nadenke oor religieuse en teologiese taal; (b) die noodsaaklikheid van selfkritiek; (c) die afwesigheid van 'n gesprek oor die 'Christian thing' en oor 'Wissenschaft'; (d) skeptisisme oor die universele aansprake oor die 'natuur' of 'rede' van die mens (vgl Kelsey 1993:147-150).

\section{4 'n Benadering tot die praktyk van die bediening}

Hough \& Cobb (1985) reken dat ons die teologiese skool as 'n professionele skool moet verstaan met as primère doel die opleiding van die kerkleierskap. Vir hulle gaan dit oor die aard en die doel van die kerk, die gemeenskap van gelowiges wat deel het aan 'n gemeenskaplike en besondere Christelike identiteit. Die klem val op die 'Christelike verhaal' van God se verlossingswerk in die geskiedenis en nie op 'n onderliggende universele 'essensie' of struktuur nie. Daar is twee dinge wat hierdie teologiese opleiding teologies en wetenskaplik maak: (a) historiese navorsing oor die 'Christelike verhaal' om sodoende die kerkleiers se greep op hulle identiteit te verstewig, en (b) navorsing oor bevindinge oor die wêreld om toekomstige leiers vir aksie in dic wèreld voor te berei (vgl Kelsey 1993:157-173, 194196). Hierdie benadering beklemtoon die enkele verhaal en die openbare aksie wat daaruit moet voortspruit en ontkom sodoende aan subjektiwiteit maar hou moontlik nie genoeg rekening met die demonstreerbare pluralisme van die 'Christelike ding' nie (vgl Kelsey 1993:170-173 en 196). 


\section{5 'Visie' en 'goeie oordeel' as benadering}

Hoe versoen ons die karaktervorming of habitus van die Atene-model met die wetenskaplike inslag van die Berlyn-model? Wood (1985) wil hierdie skaakmatposisie deurbreek deur ' $n$ radikale aanspassing van die wyse waarop ons die sentrale vrae vra. En dit doen hy ten opsigte van twee belangrike idees oor teologie, naamlik (a) die spanning tussen die pogings om aan te dui dat teologie die hele mens wil betrek omdat dit iets 'subjektiefs' en persoonlik is teenoor die siening dat teologie iets 'objektiefs' en van openbare belang is; en (b) die idee dat teologie van teorie na praktyk beweeg.

Die oorkoepelende doel van teologiese opleiding is vir Wood teologiese ondersoek. Dan is die vraag natuurlik: Wat is teologie? Wood $(1985: 32,93)$ verwerp die idee dat teologie universeel geldige 'objektiewe' waarhede of feitlikhede is (in teenstelling met Farley) asook die idee dat dit 'objektief' is in sy doelstelling om professionele kerkleiers op te lei (teenoor Hough \& Cobb). Wood volg Farley se idee van teologie as habitus maar wysig die definisie daarvan na: 'A habitus is a disposition for some activity' (Kelsey 1993:201). Teologie is dus 'n aktiwiteit, naamlik 'n 'ondersoek' wat die hele persoon as agent of doener betrek. Dus vir Wood (1985:334): '.. it is the activity of theology - theology as inquiry - which is theology in the primary sense. It is the "active" sense of the term which is prior; the "subjective" and "objective" senses are both derivative from it, both logically and chronologically'. Op dié wyse verander hy die vraagstelling oor subjektief/objektief heeltemal.

Dit bring ons by die tweede vraagstelling, naamlik van teorie-na-praktyk wat uitloop op die vraag: Watter soort aktiwiteit is teologie as ondersoek/navorsing? Vir Wood (1985:21) is teologie 'critical inquiry into the validity of Christian witness'. Teologie is maar net een van die komponente van 'n reeks aktiwiteite wat Wood met die term 'witness' omvat. Vir hom is teologie nie teorie wat op die praktyk toegepas word soos vir Stackhouse nie, maar dit is ' $n$ inherente deel van die Christelike 'ding' of 'getuienis'. In plaas van die dubbeldoor 'teorie/praktyk' gebruik Wood 'vision' en 'discernment' in sowel ondersoek as in ander tipes handelinge. 'Goeie oordeel' of 'onderskeidingsvermoë' dui op insig in die eiesoortige aard van 'n spesifieke ding of situasie en 'visie' dui op die algemene oorsigtelike verstaan van 'n hele reeks gegewens of voorwerpe (Wood 1985:67-68). Dié twee het mekaar nodig en is albei essensieel vir teologiese refleksie (Wood 1985:72-73). Hulle albei verskaf inligting vir die praktyk en word op hulle beurt daardeur ingelig. Teologiese navorsing word nie op die 'aktiwiteit' toegepas soos teorie op die praktyk nie want hierdie navorsing is reeds deel van die aktiwiteit en verg sowel 'n algemene sinoptiese oorsig (visie) as insig in die besondere (goeie oordeel/onderskeidingsvermoë). 
Nou kan ons verder bepaal watter sonrt kritiese ondersoek teologiese navorsing is as dit die geldigheid van die Christelike getuienis moet bepaal. Teologiese ondersoek moet selfkritiek op die wese en aktiwiteit van die Christengemeenskap toepas (Wood 1985:38). Die belange ('interests') van hierdie gemeenskap moet die ondersoek stuur en struktureer. Teologiese ondersoek of navorsing is teologies nie vanweë die aard van sy inhoud (die Christelike getuienis) nie, maar deur sy belange in sy stof. Ons mag byvoorbeeld belangstel in die letterkundige waarde van die Christelike getuienis, of in die geskiedenis, of in die sosiale rol daarvan, maar navorsing wat daardeur aangedryf word, is literêre kritiek, of geskiedenis, of sosiale analise, maar nie teologie nie. Wat dit teologie maak, is die belange in dit wat dit op sigself getrou maak aan die Christelike getuienis as sodanig. Wat navorsing in die Christelike getuienis Christelike teologie mak, is dat dit gerig word deur 'n belange om daardie getuienis self te beoordeel aan die hand van standaarde wat juis daarop van toepassing is as Christelike getuienis (vgl Kelsey 1993:204).

Kritiese ondersoek na die geldigheid van die Christelike getuienis is nie 'n enkelvoudige aktiwiteit nie, maar het drie dimensies wat ons in drie vrae kan uitdruk: (a) Is hierdie stuk getuienis eg Christelik? As Christelike getuienis, verteenwoordig dit werklik Jesus Christus? (Wood 1985:39). Ondersoek op grond van hierdie vraag noem Wood (1985:42) 'historiese teologie' wat vir hom Bybelondersoek insluit; (b) Is hierdie getuienis waar? (Wood 1985:39). Dit noem hy 'filosofiese teologie' wat die beginsels wat betrekking het op verstaan en op kritiek, moet bloot lê. Dit het dus met die metodologie van teologeise navorsing te doen (Wood 1985:45). Dit gaan egter verder as net die identifikasie van kriteria en prosedures van beoordeling en sluit die werklike oordeel oor die betekenis en die waarheid van die Christelike getuienis in (Wood 1985:46); (c) Word hierdie getuienis konkreet uitgeleef? Hou dit toepaslik verband met sy konteks? (Wood 1985:40). Dit noem Wood 'praktiese teologie', wat gebruik maak van sielkunde, sosiologie, antroplogie, geskiedenis, ensovoorts 'to enquire about the relationship between the content and intention of Christian witness and its context' (Wood 1985:48). Hierdie drie dimensies van die ondersoek na die geldigheid van die Christelike getuienis is in elke opsig (getrouheid aan sigself, waarheid en toepaslikheid) as historiese, filosofiese en praktiese teologie onderling afhanklik van mekaar (Wood 1985:67). Hulle is nie drie stappe in 'n reeks van aktiwiteite nie. Teologiese navorsing verg 'n dialektiese verhouding tussen 'visie' en 'onderskeidingsvermoë' in elkeen van hierdie drie dimensies (Wood 1985:69).

Wood (1985:50-51 en 71-72) voeg nog twee 'dissiplines' by hierdie drie by, naamlik sistematiese teologie en teologiese etiek. Sistematiese teologie se belange lê in die eenheid van die eerste drie. Sistematiese teologie formuleer kritiese en 
konstruktiewe voorstelle om die ander dissiplines omvattend te integreer en sodoende die egtheid, waarheid en toepaslikheid van die Christelike getuienis in sy geheel en in sy besonderhede te bewaar (vgl Kelsey 1993:210-211).

Die belange van teologiese etiek lê ook in die behoud van die eenheid van die ander drie in die algemeen, maar dan in die besonder die 'validity of Christian witness concerning human conduct' (Wood 1985:54). Praktiese teologie moet die getuienisgehalte van die Christelike getuienis bepaal en teologiese etiek moet die Christelike getuienis as gedrag beoordeel (Wood 1985:55).

Wat is die opvoedkundige waarde van teologiese navorsing? Dit stel die navorser in staat om nie net 'n klinkklaar weloorwoë oordeel oor 'n saak te vorm nie, maar dit gee eerder aan hom die vermoë tot so 'n oordeel (Wood 1985:80). Dit verg egter visie en onderskeidingsvermoë. Teologiese opleiding stel nie studente in besit van 'n 'teologie' nie, maar dit verskaf aan hulle die vermoë om teologiese oordele wat saak maak, te vorm, te hersien en te gebruik. Visie en goeie oordeel word sodoende in die praktyk uitgestal (Wood 1985:82). Hoe word hierdie oordeel gevorm? Deur mense in die aktiwiteit van teologiese ondersoek betrokke te kry. En dit het baie te make met die vrae wat in elke kursus in die onderrig- en leerproses gevra word. Die allerbelangrikste vraag is: Hoe dra hierdie stof by tot die beoordeling van die geldigheid van die Christelike getuienis? Uitmuntende teologiese skoling gaan gepaard met die vermoë tot 'n nougesette en gedissiplineerde wetenskaplike benadering. In teologiese skoling moet die klem val op hoe om te dink eerder as wat om te dink (Wood 1985:81).

\subsection{6' 'n Voorlopige beoordeling .}

'n Definisie van teologie hang grootliks af van die bron van teologiese kennis. Is dit slegs 'goddelike openbaring' dan is dit 'n normatiewe uitgangspunt wat dit uitsluit van 'wetenskaplike ondersoek' volgens die siening van Schleiermacher en die Berlyn-model. Is dit 'menslike ervaring' of selfs 'Christelike getuienis' dan is die vraag of dit nie sy identiteit, die 'transendente' aspek verloor nie. Dit is met ander woorde ' $n$ kenteoretiese vraagstelling. Vanuit 'n Afrika-perspektief dwing Gyekye (1987:201-202) in die rigting van die transendente met ' $n$ derde kenbron wat hy naas die (Westerse) rede en ervaring onderskei, naamlik paranormale waarneming in spiritisme, waarsèery en toordery in die Afrika-tradisionele religie. 'Openbaring' is natuurlik 'n geloofsaanname wat as vooronderstelling onder die 'Christelike getuienis' ter diskussie gestel behoort te word en nie as 'n 'finale waarheid' wat 'n akademiese argument by die wortel afsny nie. God het Hom immers antropomorfies aan die mens geopenbaar. 
Karaktervorming as habitus en die akademiese inslag van teologiese opleiding is twee aspekte daarvan wat ons op 'n kontinuum kan plaas. Dit kan ons help om die hele spektrum van godsdienstige opvoeding te dek - vanaf die Christelike opvoeding van die kleuter tuis tot die doktorale studies van die akademikus. Opvoeding in die 'Christelike getuienis' moet immers altyd albei hierdie bene tot 'n mindere of meerdere mate insluit al na gelang van waar die klem val. Dit deurbreek sommer ook die stereotipe strukturering in die tradisionele teologiese dissiplines.

Wood (1985:21) se definisie van teologie as 'critical inquiry into the validity of Christian witness' lé egter ' $n$ beperking op die verskeidenheid of pluralistiese aard daarvan. Dit het te make met die 'mono-religieuse karakter' van sy benadering. Knitter (1992:418) som dit só op: 'Theological educators are going about their job on the basis of an exclusive, or too restrictive, use of Christian tradition and experience. They have closed themselves to, or are not sufficiently open to, other religious traditions and identities'. Knitter (1992:422-424) bepleit 'n gespreksmodel (a conversational model) tussen Christelike teologie en godsdienswetenskap (Religious Studies) waaroor hy hom verder soos volg uitlaat:

If some such conversational model is indeed part of the hermeneutical task, there will have to be a major re-structuring of theological education. More precisely, the revisionist method of theology will have to explicitly recognize that 'tradition' as a source for the theological task cannot be understood only as Christian tradition. By itself, Christian tradition is both incomplete and inaccessible for the work of theology.

(Knitter 1992:424)

Volgens Ogden (1986:114) is Christelike teologie en godsdienswetenskap aanmekaar verbind deur hulle gemeenskaplike bestaansgrond en ervaringsveld wat hy soos volg formuleer: 'to ask about the meaning and truth of religion' en 'our basic faith in the ultimate worth of life' (vgl Thiemann 1990:69). Dit beteken dat ons Wood (1985:21) se definisie vir teologie moet aanpas om te lees: 'critical inquiry into the validity of religious witness' om sodoende alle godsdienste in te sluit.

\section{DIE SUID-AFRIKAANSE TEOLOGIE}

\subsection{Ter inleiding}

In Suid-Afrika het teologiese opleiding die oopgetrapte pad van die klassieke modelle gevolg wat net soos toe ook hier sterk deur ons sosiale, politieke en kulturele konteks bepaal is. Aanvanklik het die koloniste teruggekeer na hulle 
tuislande vir opleiding in hulle denominasie en bediening, maar later het seminariums hier te lande ontstaan as gevolg van verskillende redes (vgl Deist $\mathrm{s} a: 3$ ).

Net soos in ander lande is teologiese opleiding in Suid-Afrika kompleks en heterogeen. Dit sluit in die hele spektrum van kerklike kolleges, seminariums, Bybelskole en teologiese fakulteite vir spesifieke denominasies of wat in enkele gevalle ekumenies saamgestel is (vgl Bosch 1992:8). Daar is ook ' $n$ hele aantal departemente in Bybelkunde en Godsdienswetenskap of 'Religious Studies'. Indien my berekening korrek is, word daar aan sewentien Suid-Afrikaanse universiteite in een of ander vorm teologiese opleiding - in die breedste sin van die woord verskaf. Die blanke Afrikaanse kerke van Gereformeerde/Hervormde inslag was in die verlede die beste daaraan toe. Daar is min twyfel dat ' $n$ nuwe politieke bedeling nie sal voortgaan met hierdie bevoordeling deur dit met die geld van belastingbetalers sonder meer te subsidieer nie. Daarby kan gevoeg word dat teologiese opleiding aan universiteite uitsluitlik tot die voordeel van die Christendom geskied het, behalwe in enkele gevalle waar aanhangers van ander gelowe by departemente vir Godsdienswetenskap ingeskryf was. Dit sal verstandig wees vir kerklike fakulteite om ten minste ekumenies te word en om afstand te doen van kerklike voorskrifte oor die aanvaarbaarheid al dan nie van sekere grade soos die BD in die verlede. Selfs die toevoeging van seminariums as verwyderde kampusse om 'n ekumeniese beeld te verkry, sal waarskynlik met agterdog bejeën word en grade wat op dié wyse toegeken word, kan moontlik as 'koloniale grade' afgemaak word. In die lig van die rol wat politiek in die stigting van die meeste kerklike fakulteite gespeel het, sal hierdie nuwe wyse van die rekonstruering van teologiese opleiding moeilik gestuit kan word.

Daar is veral drie aspekte van teolngiese opleiding in ons land wat ernstige aandag verg, te wete teologisering, kontekstualisering en pluralisering.

\subsection{Die vraag na die teologiese aard}

Daar is tans hier te lande nog min besin oor die teologiese aard of te wel die 'eenheid' van teologiese opleiding. Ons vind wel enkele aanduiders dat hierdie gesprek ook hier begin momentum verkry. ' $n$ Wegbereider in dié verband is sekerlik die verskyning van Van Huyssteen se Teologie as kritiese geloofsverantwoording: Teorievorming in die sistematiese teologie in 1986. David Bosch het met die opening van die Fakulteit Teologie aan die Universiteit van Suid-Afrika aan die begin van 1991 ' $n$ rede gelewer oor 'The nature of theological education' waarin hy die drie 'publieke' (akademia, die kerk en die gemeenskap) van teologiese opleiding aan die orde gestel het. Dit het gelei tot 'n indringende diskussie daaroor in daardie jaar. Dit was veral Goosen (1992:24-34) wat op Bosch gereageer het met sy artikel 'Die teologiese onderwys as dialogiese gebeure - 'n perspektief. Hierop kom ons later terug. 
Deist (sa:302) praat van "n nuwe klem op die geloofsperspektief" in die teologie en laat hom soos volg daaroor uit:

As ons dan ons vakgebied teologie noem, impliseer dit vanselfsprekend ' $\mathrm{n}$ wèreldbeskouing waarin die supranaturale, en by implikasie God, as 'n realiteit aanvaar word, met ander woorde 'n teïstiese wêreldbeskouing ... As ons van ons vakgebied as teologie praat, veronderstel ons dus dat die werklikheid groter is as die natuurlike en sigbare wèreld. Maar ook nog meer as dit: noem ons ons val:gebied teologie, impliseer dit dat ' $n$ mens sinvol en samehangend oor die sigbare wereld en sy verhouding tot die onsigbare kan praat.

Deist se siening omvat dus sowel die habitus (die geloofsperspektief) as die akademiese aspek van teologie.

Rossouw (1990:63-71) onderskei drie basiese fasette van teologiese onderwys, naamlik intellektuele vorming, institusionele voorbereiding en professionele opleiding. Oor intellektuele vorming sê Rossouw (1990:63): 'Teologiese onderwys moet mense leer om teologies te dink, om teologiese vrae reg te kan stel en op die regte wyse na teologiese antwoorde te kan soek'. Institusionele voorbereiding is uiteraard gerig op 'die kerk waarin die teologies geskoolde 'n tuiste moet vind en leiding moet gee'. Met professionele opleiding bedoel Rossouw (1990:64) 'die opleiding vir die spesifieke vereistes wat die vervulling van die predikantsamp stel'. Dit wil voorkom asof die teologiese aard van teologiese onderwys vir Rossouw (1990:63) lê in 'die skoling in die teologie as 'n denkdissipline met 'n eie metodologie en problematiek en met 'n eie ontwikkelingsdinamiek en ontwikkelingslogika'. Hy spel egter nie uit wat hierdie 'eie metodologie en problematiek' behels nie. Dit sou ' $n$ aanduiding gee van wat dit beteken om mense teologies te leer dink.

Le Roux (1992:291-300) is veral bekommerd oor die aard en die plek van teologiese opleiding in 'n toekomstige Suid-Afrika. Die fakulteit van die Nederduitse Gereformeerde Kerk 'het nie ontstaan of bestaan tans nie vanweë akademiese redes nie' maar het voortgekom uit die sentimente en oortuiginge van die kerklike gemeenskap. Le Roux (1992:293) oordeel gevolglik: 'Indien ons aan die universiteit wil voortbestaan, sal ons self met die instrumente van wetenskapsteorie en denkmodelle vir ons 'n plekkie in die universiteitsklip moet uitkap'. Daar is volgens hom drie minimum eise vir die wetenskaplike aard van teologie, naamlik die stelligheidseis, die eis van koherensie en van kontroleerbaarheid. Vir Le Roux is die wetenskaplike aard van teologiese opleiding belangrik en om dit te waarborg moet dit aan 'n universiteit geskied. Dit wil voorkom of Le Roux (1992:294-295) ten gunste van die idealistiese universiteitsidee ('n soeke na die waarheid terwille van 
die waarheid) kies bo 'n funksionele idee (waarvolgens beroepsopleiding die hooftaak is). Le Roux dui egter nie duidelik aan wat teologiese opleiding teologies maak selfs al sou dit aan die akademiese eise van 'n universiteit beantwoord nie. Is dit teologies bloot omdat dit aan 'n 'kerklike fakulteit' gedoen word? Dit is 'n moontlike indruk wat 'n mens kry.

\subsection{Kontekstualisering}

In sy rede ter herdenking van die 130-jarige bestaan van die Kweekskool op Stellenbosch bekyk Rossouw (1990:66) die sosiale en kuiturele milieu waarmee teologicse onderwys in wisselwerking tree vanuit 'n globale, kontinentale en nasionale perspektief. Wanneer hy die kontinentale perspektief oorweeg, verkies hy om in die teenoorgestelde rigting, naamlik die proses van 'modernisering' in plaas van 'Afrikanisering' te dink (Rossouw 1990:66). Onder modernisering verstaan hy die 'pynlike oorgang...van 'n rustige agrariese kultuurpairoon na 'n dinamiese industriële en tegnologies gestempelde kultuurpatroon' (Rossouw 1990:66) wat vir teologiese onderwys inhou die operasionalisering van kennis, sekularisering (geloof in God maak geen verskil in ons daaglikse lewe nie) en toenemende maatskaplike differensiëring (Rossouw 1990:67-68).

Rossouw is natuurlik reg in sy oordeel hierin, maar een van die basiese vrae wat teologiese opleiding in Afrika teologies maak hang saam met die Christelike of godsdicnstige identiteit van Afrika: Wat behels die 'Christelike/godsdienstige getuienis' van Afrikane? Dit het te make met 'inkulturasie'. Afrika-tradisionele religie is deel van die kultuur van Afrika, maar hoe word die Christendom of enige ander religie deel van Afrika? Meer nog: hoe leer mense - wat nie in 'n westerse rasionaliteit deel nie - om teologies te dink? Voeg daarby die ingewikkelde moderniseringsprosesse en teologisering bied groot probleme vir teologiese opleiding in Afrika.

Kontekstualisering het nie net betrekking op 'n elitistiese professionele opleicing van predikante en teoloë in Afrika nie. Indien ons teologiese opleiding aan alle gelowiges, die laos of volk van God wil verskaf, beteken dit dat ons die amp van die gelowige as uitgangspunt vir teologiese opleiding moet neem. Oor'n kongres in 1985 in Meksiko-stad oor die tema 'Theology by the people' sê Saracco (1986:33) 'the key factor was the universal recognition of the people as the subject of theology'. In 'n opebrief van die kongresgangers aan hulle kollegas skryf hulle in Ministerial Formation 30, 39.40 soos volg: 'We need to learn to read the Bible not only with the tools of scholarship but also through the eyes of the poor and marginalised in order to understand God's message' (Saracco 1986:33; vgl West 1991:164-173). 
'n Groeiende aantal publikasies oor kontekstualisering in Afrika het in onlangse jare die lig gesien. Enkele skrywers is John Pobee (1989:1-23), Smangaliso Mkhatshwa (1990:3-8) en J J Kritzinger (1990:379-389). Ek noem en bespreek nie meer nie, want die meeste van hierdie artikels reflekteer glad nie oor die teologiese aard van teologiese opleiding nie.

\subsection{Pluralisme}

Vir 'n paar dekades is daar nou reeds die middelpuntsoekende kragte van die ekumeniese gees in swang. Die gedagte van 'n 'wèreldkerk' het sy wortels in die Tweede Vatikaanse Konsilie van die Rooms-Katolieke kerk en in die Wèreldraad van Kerke wat Protestante en Oosters-Ortodokse Kerke insluit. Desnieteenstaande bly die grootste uitdaging vir die kerk in die volgende eeu die spanning tussen die univcrsaliteit en die partikulariteit van die kerk nie alleen vir teologiese denke nie, maar ook vir nuwe kerklike strukture en pastorale strategieè.

Verder word die hedendaagse wêreld gekenmerk deur 'n groeiende pluralisme. Verstedeliking en die internasionale handel bring mense van verskillende rasse, kulture en godsdienste in daaglikse kontak met mekaar. Pluralisme vir die individu bestaan nie net uit die verskeidenheid van kulture van ander mense nie, maar ook uit die verskeidenheid 'wêrelde' waarin die enkeling daagliks beweeg. Die kulturele bronne van pluralisme, soos die tegnologiese rewolusie, internasionalisering van die ekonomie, ensovoorts is reeds goed bekend, maar die ontwikkeling van Christelike teologiese denke oor pluralisme het grootliks agterweë gebly. Die kerke was immers oortuig dat die Christelike geloof die enigste ware godsdiens is. In hierdie siening het daar groot verandering gekom. Absolutisme het plek gemaak vir paritiet, vir die erkenning van die geldigheid en relevansie van ander godsdienste.

Die tegnologiese uitdaging van pluralisme lê in: 'How can one interpret one's religious symbols in a meaningful way which is neither absolute nor relative, neither becoming indistinguishable from nor indifferent to the other, neither excluding nor offending the other' (Tang 1988:8).

Godsdienstige pularalisme geniet hoë prioriteit in Afrika aangesien die drie groot wèreldgodsdienste - Findoeïsme, Islam en Boeddisme - hier aangetref word. Dit moet gevolglik ook neerslag vind in die teologiese denke en in teologiese opleidingsprogramme. Dit is juis om hierdie rede Jat ons Wood (1985:21) se definisie vir teologie aangepas het na: 'critical inquiry into the validity of religious witness'. Daar is dan ook heelwat teoloë wat godsdienstige pluralisme aansny, soos byvoorbeeld Pobee (1989:5-7), Robinson (1940:279-292) en Knitter (1992:418-437). 
Dit bring ons by die siening van Goosen (1992:24-34) van teologie as 'dialogiese gebeure'. Sy siening verwoord hy s6: 'Herstruktureer die teologie op so 'n wyse dat dit, net soos die polifone roman, 'n polifone teologie sal wees' (Goosen 1992:25). Volgens hom moet teologie-beoefening, net soos die polifone roman drie eienskappe vertoon, te wete 'n dialogiese aard, 'n perspektiviese aard, en 'n vrolike relatiwiteit. Goosen se artikel was nie net 'n reaksie op Bosch (1992:8-23) nie, maar het ook as wegbereider gedien vir die moontlike naamsverandering van die Fakulteit Teologie aan Unisa. Die naam van die Fakulteit sal na ministeriële goedkeuring heet: Fakulteit Teologie en Godsdienswetenskap (Faculty of Theology and Religious Studies) om juis voorsiening te maak vir die insluiting van ander godsdienste in die definisie van teologie en vir 'n 'dialogiese gebeure' as metode vir teologie-beoefening en -opvoeding (vgl ook Mkhatshwa 1990:5-7).

\section{DIE EINDDOEL VAN TEOLOGIESE OPLEIDING - 'N SAMEVATTING}

Die sentrale vraag lui: Wat maak teologiese opleiding teologies? Hierop is verskillende antwoorde gegee in die literatuur wat ons bestudeer het. Die hoofpunte kan ons soos volg saamvat:

\subsection{Eenheid en verskeidenheid}

In ons bestudering van die aard en doel van teologiese opleiding was daar verskillende sienings oor die eenheid en pluraliteit daarvan. Ons kan die sentrale positiewe idee soos volg formuleer: Fokus op die einddoel van teologiese opleiding en nie op die metodes of die struktuur daarvan nie. Dit beteken: konseptualiseer teologiese opleiding teologies en nie funksioneel of formeel nie. Dit beteken nie metodes en strukture is onbelangrik nie, maar dat ons eers vir onsself moet uitmaak: Wat is teologie? Prakties beteken dit dat ons nie maar net nuwe kursusse of departemente oor bevrydingsteologie en vroue-teologie kan aanlas sonder om duidelikheid te hê oor die einddoel van ons teologiese opleiding nie. Onder 'teologie' verstaan ek - anders as die meeste skrywers waarna verwys is - nie net Christelike teologie nie, maar ook die insluiting van ander godsdienste.

Dit beteken dat die einddoel meer is as: (a) die opleiding van predikante; (b) 'n individualistiese benadering tot die mens as persoon. In Afrika geld die Xhosagesegde immers: umntu ungumntu ngabantu = 'n mens is 'n mens deur (ander) mense; (c) een onderliggende 'struktuur', 'essensie' of 'identiteit' van geloof as sodanig wat maklik kan lei na 'n ideologisering van daardie besondere essensie; (d) dit moet in diens staan van en nou verbonde wees aan die maatskappy wat dit wil dien. Daarom is 'afstandsonderrig' ' $n$ uiters geskikte onderrigwyse vir teologiese opleiding - dit neem nie die student weg uit sy eie konteks, die maatskappy waarin hy leef, werk en studeer nie; en (e) dit moet 'n 'dialogiese gebeure' wees. 


\subsection{Wisselwerking tussen karaktervorming en akademiese uitmuntendheid}

Dit gaan hier om die spanning tussen, wat Kelsey (1993) noem, die Atene-model en die Berlyn-model. Die twee modelle verskil in hulle siening van die mens en sy/haar rede. Die karakteristieke van die mens volgens die Atene-model 'is the capacity of reason in intuitive, cognitive judgement to apprehend the ultimate principle of being and of value - that is, God. This intuitive act is the very heart of rationality; it is the act of knowing that provides the foundation of all other knowing' (Kelsey 1993:26). Daarteenoor oordeel die Berlyn-model dat 'the characteristic defining human being is reason's capacity to test and if necessary correct any and all "intuitions" - that is, its capacity to engage in disciplined and orderly critical inquiry'(Kelsey 1993:26).

'n Positiewe stelling oor teologiese opleiding in dié verband kan ons soos volg formuleer: Fokus op die beweging van teologiese opleiding tussen hierdie twee pole as 'n teologiese aangeleentheid. Daar is natuurlik verskillende sieninge oor hierdie 'beweging' wat gegrond is op dié spesifieke benadering se siening van teologie: (a) vanaf die bron (van 'openbaring', of 'wysheid oor God' - Farley) na persoonlike toeeiening; (b) vanaf die bron na die toepassing van die bron op die lewe (soos in kerkleierskap - Stackhouse); (c) vanaf die bron na leerstellings in die bron, na die toepassing van die leerstellings op die lewe, ensovoorts.

Hierdie teenstelling lei maklik tot twee uiteenlopende oorkoepelende einddoelstellings van teologiese opleiding wat in wese onsamehangend is en teenoor mekaar staan. Hierdie spanning is eintlik onvermydelik. Oorvereenvoudig gestel, kan ons sê dit is 'n spanning tussen karaktervorming of spiritualiteit en akademiese uitmuntendheid. ' $n$ Gesonde wisselwerking kan egter bestaan waar die beweging rekening hou met die teologiese aard van elkeen. Waar daar byvoorbeeld 'n gesonde onderlinge samewerking tussen kerklike seminariums en teologiese fakulteite aan universiteite bestaan kan dié wisselwerking 'n groot deel van die spanning neutraliseer.

\section{8. 'N EIE SIENING EN DIE IMPLIKASIES DAARVAN}

Ek sou - voorlopig natuurlik - teologiese opleiding breër en omvattender as die huidige (tradisionele) siening wil beskou en dit soos volg wil definieer: Teologiese opvoeding/opleiding is ' $n$ dialogiese gebeure waarin mense meedoen aan kritiese ondersoek oor die geldigheid van religieuse getuienis.

Hierdie siening beklemtoon: (a) die teologiese aard van teologiese opvoeding as 'n teologiese saak; (b) die omvattendheid van teologiese opleiding wat myns insiens kategeseskole, Bybelskole, seminariums, teologiese fakulteite, godsdiensonderwysinstellings, ensovoorts insluit: Dit bly teologiese opvoeding al verskil die verskillende vlakke ook; (c) die inklusiewe aard daarvan aangesien dit oor 'godsdiens' as sodanig gaan sonder die uitsluiting van een of ander vorm daarvan. 
Ek noem enkele voor die hand liggende implikasies:

- Die universele en partikuliere aard van godsdienste verg erkenning - sowel fragmentering as sinkretisme word uitgesluit;

* Herbesinning oor die eenheid en verskeidenheid of pluraliteit is noodsaaklik;

- 'n Wisselwerking tussen spiritualiteit en akademiese voortreflikheid moet gesoek word;

- Samewerking tussen verskillende soorte inrigtings is wenslik - die stigting van 'n oorkoepelende vereniging vir opvoeders in godsdiens(te) moet oorweeg word;

* Die herstrukturering van inrigtings moet ernstig oorweeg word om voorsiening te maak vir 'n veranderde siening; en

- Samewerking om die plek van godsdiensonderwys in staatsondersteunde inrigtings te verseker.

\section{Literatuurverwysings}

Bosch, D J 1992. The nature of theological education. TE 25 (1), 8-23.

Bujo, B 1988. Latin America: Popular theological education. Pro Mundi Vita 4, 13-18.

Burden, J J 1992. Old Testament scholarship in the (South) African context: A dialogical approach, in Wessels \& Scheffler 1992:33-56.

Deist, F E (samesteller) $s$ a. Bybelwetenskappe in die Nederduitse Gereformeerde Kerk 1858-1990, vol 2, in Deist, F E (projekleier), Wetenskapsteorie en vakmetodologie in Bybelwetenskaplike navorsing in Suid-Afrika. Pretoria: RGN.

Farley, E 1983. Theologia: The fragmentation and unity of theological education. Philadelphia: Fortress.

Farley, E 1988. The fragility of knowledge: Theological education in the church and the university. Philadelphia: Fortress.

Ferris, R W 1990. Renewal in theological education: Strategies for change. Wheaton: Billy Graham Center.

Goosen, D P 1992. Die teologiese onderwys as dialogiese gebeure - 'n Perspektief. TE 25/1, 24-34.

Gyekye, K 1987. An essay on African philosophical thought: The Akan conceptual scheme. Cambridge: Cambridge University Press.

Hough, J C \& Cobb, J B 1985. Christian identity and theological education. Chicago: Scholars Press.

Kelsey, D H 1993. Between Athens and Berlin: The theological education debate. Grand Rapids: Eerdmans. 
Knitter, P F 1992. Religious pluralism in theological education. Anglican Theological Review 74/4, 418-437.

Kritzinger, J J 1990. Gereformeerde teologiese opleiding en die toekoms. In die Skriflig 24/3, 379-389.

Le Roux, J H 1992. Op die breuklyn (oor universiteit en teologiese fakulteit). NGTT 33/3, 291-300.

Macquarrie, J 1977. Principles of Christian theology. 2nd ed. New York: Scribner. Mkhatshwa, S 1990. The role of contextual theology in a changing South Africa. JTSA 72, 3-8.

Moltmann, J 1980. Experiences of God. Philadelphia: Fortress.

Mud Flower Collective 1985. God's fierce whimsy: Christian feminism and theological education. New York: The Pilgrim Press.

Ogden, S 1986. Theology and Religious Studies: Their difference and the difference it makes, in On Theology, 102-120. San Francisco: Harper and Row.

Padilla, C R (ed) 1986. New alternatives in theological education. Grand Rapids: Nueva Creacion.

Pobee, J S 1989. Comments on the future of theological education in Africa. Scriptura 28, 1-23.

Robinson, G 1990. Theological education in the third world. The Asian Joumal of Theology 4/1, 279- 292.

Rooy, S 1986. Historical models of theological education, in Padilla 1986:51-72.

Rossouw, H W 1990. Teologiese onderwys ná 130 jaar: 'n Toekomsperspektief. NGTT 31/1, 63.71.

Saracco, J N 1986. Search for new models of theological education, in Padilla 1986:25-49.

Stackhouse, M L 1988. Apologia: Contextualization, globalization, and mission in theological education. Grand Rapids: Eerdmans.

Tang, E 1988. Pluralism as fact and value. Pro Mundi Vita 4, 5-9.

Taylor, M J 1984. Changing pattems of religious education. Nashville: Abingdon.

Thiemann, R E 1990. The future of an illusion: An inquiry into the contrast between theological and religious studies. $T E$ 26/2, 66-85.

Tracy, D 1981. The analogical imagination. Christian theology and the culture of pluralism. New York: Crossroads.

Van Huyssteen, J W V 1986. Teologie as kritiese geloofsverantwoording: Teorievorming in die sistematiese teologie. Pretoria: RGN. (RGN-studies in Navorsingsmetodologie 2.) 
Wessels, W \& Scheffler, E (eds) 1992. Old Testament science and reality: A mosaic for Deist. Pretoria: V'erba Vitae.

West, G 1991. Biblical her,neneutics of liberation: Modes of reading the Bible in the South African context. Pietermaritzburg: Cluster Publications. (Cluster monograph series 1.)

Wheeler, B G 1991. Introduction, in Wheeler \& Farley 1991:7-33.

Wheeler, B G \& Farley, E 1991. Shifting boundaries: Contextual approaches to the structure of theological education. Westminster: Knox.

Wood, C M 1985. Vision and discemment. Atlanta: Scholars Press. 